DOI https://doi.org/10.18551/rjoas.2018-09.38

\title{
THE EFFECT OF CREDIT EXPERIENCE, NET INCOME, CREDIT TERM AND BUSINESS EXPERIENCE TOWARDS THE AMOUNT OF PEOPLE'S BUSINESS CREDIT FOR AGRIBUSINESS SECTOR: A CASE STUDY AT PT BANK RAKYAT INDONESIA PERSERO TBK OF BARON UNIT, SOLO BRANCH OFFICE, CENTRAL JAVA
}

\author{
Indradiartha Reni Jasmin Ardiana*, Rahayu Endang Siti, Sutrisno Joko \\ University of Sebelas Maret Surakarta, Indonesia \\ *E-mail: jasmin.ardiana@gmail.com
}

\begin{abstract}
The research aims to determine the effect of the credit experience, net income, credit term and business experience on the amount of People's Business Credit (KUR) receiving for agribusiness sector at PT Bank Rakyat Indonesia Persero Tbk Baron Unit, Solo Branch Office. Micro and Small Medium Enterprise's (MSMEs) have become an important part of Indonesia's economic system. However, as a majority of businesses, MSMEs have limited accessibility to formal institutions. This obstacle makes the government provide credit guarantees through the People's Business Credit (KUR). "People's Business Credit (KUR)" is a superior credit product of PT Bank Rakyat Indonesia Persero Tbk. It is a micro credit that is given to MSMEs that are feasible but not bankable yet to help agribusiness entrepreneurs to scale up their businesses size. Purposive sampling technique was adopted. Primary data is collected through a questionnaire distribution from 55 respondents of debtors of People's Business Credit on agribusiness sector at BRI Baron Unit, Solo Branch Office, Central Java. The data were selected and analysed using descriptive statistics and Multiple Regression Models. The research showed that the credit experience, net income, credit term, and business experience have a significant effect on the amount of People's Business Credit (KUR) for agribusiness sector at BRI Baron Unit, Solo Branch Office.
\end{abstract}

\section{KEY WORDS}

People's Business Credit (KUR), MSMEs, Micro Credit, Agribusiness

Micro, Small And Medium Enterprise's (MSMEs) have become an important part of the economic system in Indonesia. This is because MSMEs are business units that are more numerous than large-scale industrial enterprises and have the advantage of absorbing more workers and also able to accelerate the equity process as part of development (Anggraini \& Nasution, 2013). According to Ndungu, (2016) Small and medium enterprises (SME's) play a very significant role in the economy of any country. They provide employment and improve the standard of living of individuals-both the employers and employees.

In the perspective of agribusiness, the agricultural commodity has become an economic entity for the actors of businesses to develop the integration of products from upstream to downstream (Friyanto \& Saptana, 2017). The existence of the agricultural sector has been able to create a business chain from the land until business of fast food in the table. The agricultural sector is not only related to farm. But the scope of the agricultural sector is also related to off-farm, both upstream and downstream. This shows that the agricultural sector has a strategic role to realize development that can reduce poverty levels, while creating economic growth and employment (Daryanto, 2009). According to Maulidah, (2012) agribusiness systems can be interpreted as all activities, ranging from the procurement and distribution of production facilities (inputs) to the marketing of products produced by farms and agro-industries, which are interrelated with each other. Thus the agribusiness system is a system consisting of various subsystems, namely: Upstream Agribusiness / Agro-Industry Subsystem, Cultivation / Farm Subsystem, Subsystem Agribusiness / downstream Agroindustry, Agribusiness Support Services Subsystem.

Agribusiness development as economic development in the regions is also increasingly relevant, considering that currently agribusiness is the largest contributor in the economic 
structure of almost every region. The agribusiness sector is the biggest contributor in GRDP and regional exports. Likewise in employment, business opportunities in each region, mostly contributed by the agribusiness sector. Therefore, through the acceleration of agribusiness modernization in each region will directly modernize the regional economy and can solve most of the economic problems in the region (Nurif \& Mukhtar, 2010). With the contribution of agribusiness sector which is increase, can increase the income of the indonesian people so that it can improve the welfare of the indonesian people's and overcome the poverty in indonesia. the economic growth of Indonesia can be slow down because of the poverty. These problems can be overcome by increasing the income of Indonesian people's, and one of them is by helping businesses in providing capital in the form of credit in developing their business to increase business income and contribute to economic growth in Indonesia. As a business actor that has a large number of business units, MSMEs make an important contribution to economic development in expansion of employment.

As only stated by the Coordinating Ministry for Economic Affairs ( 2017) , 98 percent of companies in Indonesia are micro and small businesses but are able to contribute 57 percent of Gross Domestic Product (GDP) and absorb 60 percent of the workforce. However, micro and small businesses often face an obstacles including lack of information and access to credit, thus limiting their growth and investment opportunities. Likewise (Ratnaningtyas, Topowijono, \& ZA, 2016) said that in general the capital provision made by banks was in the form of credit. Loans into one solution that is appealing to the public, but access to credit is not easy for people who have micro, small, and medium scale. Kisaka \& Mwewa ( 2014) also said that MSMEs have limited access to credit due to insufficient capacity in providing financial services so that it becomes an obstacle in the expansion and growth of the economic sector. according to Formal instituion, MSMEs have a high risk and is not commercially viable as a result only a few MSMEs have access to formal institution such as banking. The conditions in obtaining credit becom obstacles for SMEs owners who want to develop their business becomes larger. This obstacle make the government provide credit guarantees through People's Business Credit (KUR) (Ratnaningtyas et al., 2016). As a majority of businesses, MSMEs also have limited " accessibility " of credit mainly on formal credit institutions. MSMEs with a majority of units in Indonesia only get around six percent of the national credit share, although it is suspected that with the existence of People's Business Credit (KUR), this share has increased to one fifth in recent years (Darwin, 2018).

However, with the rollout of capital funds through People's Business Credit (KUR) does not mean to override the impact of credit risk. One of the causes of credit risk is caused by the debtor's inadequacy. If the operating income of the debtor is disrupted, the obligation to pay back the party based on the credit will also be disrupted or experience delays and even experience payment failure. According to Ofonyelu \& Alimi, (2013) This failure raises questions, how is the initial screening process in lending. Screening early the strict ones have a purpose to reduce the risk of default. However, it is undeniable that the initial screening is constrained by asymmetric information which means that the borrower's information is not observed carefully.

With the low access of MSME financing to financing / banking institutions and with the prudential princip of the banking sector, this study will review how the socio-economic caracteristics of debtors of People's Business Credit (KUR) agribusiness sector at Bank Rakyat Indonesia Unit Baron, Solo Branch Office and how the credit experience, the income, credit term and business experience impact the amount of credit of the agribusiness sector from the People's Business Credit program channeled at the BRI Baron Surakarta Unit. The purpose of this study is in order to provide input to MSMEs that by knowing the influence of credit experience variables, income, credit term and business experience can increase credit access to financial institutions and increase capability so that MSEs can scale up to larger businesses. Although credit has important role for MSMEs of Agribusiness sector, only few studies are available to investigation of factors influence the disbursed credit. Therefore the result of this research maybe helpful to the formal institution (Banking), policy makers and other officials of banking and MSMEs of Agribusiness sector to enlargement the business 
and provide convenience in accessing credit. This research may also provide information to the researchers for further studies.

\section{LITERATURE REVIEW}

Agribusiness. Conceptually according to Maulidah, (2012) Agribusiness systems can be interpreted as all activities, ranging from the procurement and distribution of production facilities (inputs) to the marketing of products produced by farms and agro-industries, which are interrelated with each other. Thus the agribusiness system is a system consisting of various subsystems, namely:

1. Upstream (Upstream) Agribusiness / Agro-Industry Subsystem: including the procurement of agricultural production facilities, among others, consisting of seeds, seeds, fodder, fertilizers, drugs to eradicate pests and diseases, credit institutions, fuel, tools, machinery, and agricultural production equipment.

2. Cultivation / Farm Subsystem: farming produces agricultural products in the form of food, plantation products, fruits, flowers and ornamental plants, livestock, animal and fish products.

3. Subsystem Agribusiness / Agroindustry downstream (downstream): includes Processing and Marketing (trade system) of agricultural and processed products. In this subsystem there is a series of activities ranging from collecting farm products, processing, storage and distribution. Industries that process farm products are called downstream agroindustry. Its role is very important if it is placed in the countryside because it can be a driving force of the economy in the countryside, by absorbing / creating jobs so as to increase the income and welfare of rural communities. Agroindustry Downstream is industry processing results agriculture primary and even more large again covers industry secondary and tertiary who processes it more go on from product processed the results agriculture primary, like textile of yarn and yarn from cotton or silkworm, shoes from skin and skin from animals, industry cake from flour, and so forth.

4. Agribusiness Support Services Subsystem (Institutional): agribusiness (institutional) or supporting institution support service subsystems are all types of activities that function to support and serve and develop upstream sub-system activities, farming subsystems, and downstream sub-systems. The institutions involved in this activity are extension agents, consultants, finance, and research.

Micro Credit. Microcredit has become one of the most important tools used to combat poverty and to enhance families' wellbeing (Nader, 2008). The main characteristics of micro credit are: These loans are too small, no collateral required, mostly have weekly payments, short term such that less than one year loan, it is mostly for the women and poor people who are not eligible for borrowing the formal loan. In micro credit, the interest rates are high due to high micro credit program running cost (Nawai, 2010).

People's Business Credit (KUR). People's Business Credit (KUR) is micro credit provided by banks to Micro, Small, Medium and Cooperative Enterprises that are feasible but not bankable. The point is that the business has good business prospects and has the ability to return the installment. MSMEs and cooperatives that are expected to be able to access KUR are those engaged in the productive business sector, among others: agriculture, fisheries and maritime, industry, forestry, and financial services. Distribution of People's Business Credit (KUR) can be done directly, this means Micro, Small, Medium and Cooperative Enterprises can directly access People's Business Credit (KUR) at the Branch Office or Sub-Branch Office. The distribution of People's Business Credit (KUR) can also be done indirectly to bring services closer to micro enterprises, this means that microbusinesses can access People's Business Credit (KUR) through Micro Finance Institutions and Cooperatives, or through other linkage program activities in collaboration with the Implementing Bank (Coordinating Ministry for Economic, 2017).

Credit Experience. Credit experience is a credit history of debtors. Credit history is the information about a borrower's responsible repayment of debts that recorded in the 
Indonesian Bank (BI). Whether it is good or bad in repayment so it could be consideration for Bankers as a consideration in taking credit approval decision. It is a record of a borrower's ability to repay debts. Potential borrowers who have no credit history that demonstrates their ability to make payments on time, for example college-age young adults, may have difficulty being approved for financing. By having a credit history, the borrower demonstrate how well they can manage their credit on a limited scale before taking on larger amounts of debt. Creditors who lend money to a borrowers with bad in repayment greater risk of that borrowers with good credit. According to Lemessa \& Gemechu, (2016) Experience in credit use from the formal sources was important factors influencing formal credit use of smallholder farmers. In line with Mensah \& Agbekpornu, (2015) showed that credit access was influenced significantly by borrower experience.

Net Income. Net Income is the amount of revenue left after subtracting all expenses, taxes and costs. It is the other factor that affect your ability to get approved to access credit in formal institution. The higher the income, all other things being equal, the more credit the borrowers can access. The ability of the borrowers can be measured in making payments as a liability to the Bank by seeing their net income. So the ability to pay is seen especially in difficult times in managing the business of borrowers. Generally, the banks make credit granting decision based on both ability to repay a debt (income) and willingness (the credit report) as indicated by a history payments. In one side, Cheng, (2007) found that the household demand for micro-loans is positively correlated with household income. In the other side, Luvhengo \& Lekunze, (2017) showed that income/yr was insignificant towards access to credit. In line with Zhao et al., (2006) find that SMEs' financial variables such as income \& net profit, are not obvious to affect their ability to get bank loan.

Credit Term. Credit term is the length of time that credit accounts have been open and active. It is the length of time given to debtors to be able to pay or repay the credit. It will also be taken into consideration for Bankers in taking credit approval decision. Furthermore, the patterns and regularity of repayment over longer periods of time will give more favorably in the assessment of credit. sometimes, borrowers was suggested to continue make installment payments rather than outright pay off outstanding debt in order to continue to build up a positive credit history. According to Ajagbe et al., (2012) The period of obtaining credit is positively correlated with personal savings which shows that the longer the payback period the higher the amount of credit secured from the scheme and the higher the income generated.

Business Experience. Business experience is abilities and capacities of enterpreneurs to manage their business. Skills refer to the abilities and capacities of people who perform tasks demanded of them in a work environment. Skills can either be generic, referring to general transferable skills, or specific to certain work functions, such as managing people, computing, dealing with risk and uncertainty, or developing a new product or service (Tether et al., 2005). According to Hutadjulu \& Blesia, (2016) The age of business is one of the considerations in the business assessment by banks and investors because it can assess the stage of business and its track record undertaken over the years. The age of business has a positive effect on the perception. This indicates that the older the companies are, the better their perception about the importance of book keeping and financial reports.

Someone who has business experience is very important consideration in assessing whether the person concerned can be trusted to manage the credit facility provided. Providing credit facilities to people who do not have business experience at all in the business world, are clearly very high risk. Moreover, if the credit facilities provided in large amounts are certainly very dangerous for the bank. In the world of business, there are many face competition, the state of the economy is often changing, prices are fluctuating, government policies are always changing, so that sufficient experience is needed to deal with it (Rivai \& Veithzal, 2007). In line with Munene \& Guyo, (2013) concludes that age of the business was factor influencing non-repayment of loans. In the other side Mensah \& Agbekpornu, (2015) showed that factors such as years of business experience of Agri-SME operators was insignificant and did not influence access to credit. 
Previous Research. Previous research of credit has been widely conducted in the world. Wabei, (2012) examines important explanatory variables that influence credit demand. the result showed the size of the household, gender, age, education, total household expenditure, remittances received and residence were influence credit demand. Ofonyelu \& Alimi, (2013) observed that the banks' screening criteria was limited by the presence of information asymmetry. Adverse selection and moral hazard were observed to persist in the loan markets irrespective of the stringency of the banks' screening measures. The observed difference between estimated and ex- post default risk incidence arise because of the presence of information asymmetry. According to Ndungu, (2016) number of lending institutions, interest charged on loans, collateral security and literacy levels are the most significant factors that affect access to credit among SMEs in Murang'a. Kisaka \& Mwewa, (2014) showed that micro-credit, micro-savings and training jointly contribute positively to SMEs growth. However, the effect of training is not statistically significant. Khandker (2005) indicates that landholding determines group formation and consequently an individual's demand for credit, the education of household members also affects demand for credit. More specifically, female education has a negative effect on the amount of borrowing from microfinance programs. Balogun \& Yusuf, (2011) shows that household social capital variables (membership density index, meeting attendance index, cash contribution index \& heterogeneity index), dependency ratio and credit variables (credit distance \& interest rate) significantly explained households demand for credit. Social capital variables significantly influenced the amount of credit available from different sources. Alabi et al., (2016) identified farm size, membership of co-operative, household distance from source of credit and total amount of credit accessed as major factors influencing farmers' access to formal agricultural credit.

Hypothesis:

The effect of credit experience towards the amount of People's Business Credit.

$\mathrm{H}_{1}$ : Credit experience has a significant effect towards the amount of People's Business Credit for agribusiness sector.

The effect of net income towards the amount of People's Business Credit.

$\mathrm{H}_{2}$ : Net income has a significant effect towards the amount of People's Business Credit for agribusiness sector.

The effect of credit term towards the amount of People's Business Credit.

$\mathrm{H}_{3}$ : Credit term has a significant effect towards the amount of People's Business Credit for agribusiness sector.

The effect of business experience towards the amount of People's Business Credit.

$\mathrm{H}_{4}$ : Business experience has a significant effect towards the amount of People's Business Credit for agribusiness sector.

\section{METHODS OF RESEARCH}

The Research Location. This research location selected purposively in Bank Rakyat Indonesia for 3 months in 2017 with consideration that Bank Rakyat Indonesia PT, Tbk was the Biggest Goverment Banks with the highest amount of People's Business Credit in Indonesia.

Sampling Technique. The research sampling technique using purposive sampling method. The data were taken from questionnaire distributed to 55 debtors of People's Business Credit on Agribusiness sector at Bank Rakyat Indonesia, PT Tbk, Baron Unit, Solo Branch Office, Central Java. 55 respondents were selected base on their business on agribusiness off-farm sector which access credit from goverment program that called People's Business Credit (KUR)

Method of Data Collection. The collected data for this research were obtained mainly from primary sources. Primary sources of information were obtained using a structured questionnaire. The questionnaire were designed to extract information on; socio-economic characteristics, these range from age, sex, level of education, asset, credit experience, net income, credit term, business experience was supported with direct interview. 
Method of Data Analysis. Data for the research were analyzed using both descriptive and Ordinary Least Square (OLS) Multiple Regression Model . Objectives (i) was analyzed using simple descriptive statistics such as percentages and frequency distribution. Objective (ii) was accomplished using Ordinary Least Square (OLS) Multiple Regression Model.

Descriptive Statistic. This involved the use of the percentages distribution to analyse the data collected from the survey.

Multiple Regression Model. In order to determine the effect of credit experience, net income, credit term and business experience towards the amount of People's Business Credit (KUR) on agribusiness sector in the research location.

Multiple Regression Model with Ordinary Least Square method also used to test the hypothesis ( $\mathrm{R}^{2}$, F-test, t-test) and classical assumption (normality, multicollinearity and heteroscedasticity).

The Multiple Regression Model that was used is specified below:

$$
Y_{i}=\alpha_{0}+\alpha_{1} X_{1}+\alpha_{2} X_{2}+\alpha_{3} X_{3}+\alpha_{4} X_{4}+\mu_{i}
$$

Then, transformed into natural logarithms are as follows:

$$
\ln Y_{i}=\alpha_{0}+\alpha_{1} X_{1}+\alpha_{2} \ln X_{2}+\alpha_{3} \ln X_{3}+\alpha_{4} \ln X_{4}+\mu_{i}
$$

Where: $Y_{i}$ is the amount of People's Business Credit (KUR) for agribusiness sector (rupiah), $X_{1}$ is credit experience (1: have a good credit experience; 0 : otherwise), $X_{2}$ is monthly net income (rupiah), $X_{3}$ is the credit term (month), $X_{4}$ is the business experience (years), $\mu$ i is the term of error, $\alpha_{0}$ is the regression constant, and $\alpha_{1}, \alpha_{2}, \alpha_{3}, \alpha_{4}$ are regression coefficient.

\section{RESULTS AND DISCUSSION}

Socio-Economic Characteristics of debtors of People's Business Credit (KUR) agribusiness off- farm sector at Bank Rakyat Indonesia Unit Baron, Solo Branch Office. The results of socio-economic characteristics of the respondents are presented in Table 1. The research showed that fifty two point seventy three percent of the respondent were female, while fourtyseven point twentyseven percent were male. Thus female gender dominates the agribusiness enterpreneurs in the research location. The female implies that they take the loan to increase their income by expanding their business. Altough their business is landless in urban area but they can prove that female gender can easily having access to formal institution especially at Bank Rakyat Indonesia Unit Baron, Solo Branch Office. This agrees with the findings of (Taj et al., 2008) Generally access of microcredit proved the opportunity for the poor people specially the landless households and the female, to invest this in income generating activities. It also provides the self-employment opportunity to improve the economic condition of country. Table 1 showed that eighty (80) percent of the respondent had age ranges between 31-60 years. this research implies that mayority of respondents are within the age bracket of productive, innovative and active in doing their business or their work. This research agrees with the findings of (Alabi et al., 2016) the implication of this result is that farming in the area enjoys higher patronage by active matured people who are energetic enough to withstand the stress involved in farm operations. Furthermore, fiftyfour point fiftyfive percent had formal education at senior high school level. This research implies that mayority of respondents were literate.

Credit Experience. Table 1 shows that eighty five point fourty five $(85,45)$ percent respondent have a good previous credit experience from formal institution. In the otherside fourteen point fifty five $(14,55)$ percent of respondent have a delay of credit payment and also respondent that have not credit experience include in this percentage.

Net Income. Table 1 also shows the distribution of respondent based on net income. Thirthy eight point eighteen $(38,18)$ percent of respondent have a net income 1 until 2 million rupiah and the second percentage has income less than and equal to 1 million rupiah $(36,36$ 
percent), thirth percentage has net income between 2 until 3 million rupiah (23,64 percent) and there is a net income of more than 3 million which is 1,82 percent.

Credit Term. Table 1 shows the distribution of respondents based on credit term. The most respondents have a credit term of 24 months $(50,91 \%)$. The credit term affects the debtor's ability to pay, which must be calculated by the officer's BRI in assessing the installments paid monthly by the debtors. The second percentage of credit term was 36 months $(25,45 \%)$, then 18 months $(12,73 \%), 12$ months $(5,45 \%)$ and 60 months $(3,64 \%)$ and the last was 48 months $(1,82 \%)$. The credit term of 48 until 60 months is specifically for debtors with investment credit purposes while the credit term of 12 months up to 36 months is intended for the debtors with the aim of working capital credit.

Business Experience. Based on business experience, it can be seen that the most respondents have age of the business less than 5 years $(38,18 \%)$ and the average respondent has a business for 1 year. Then the percentage of second, third, fourth and fifth is $5-10$ years $(36,36 \%), 10-20$ years $(14,55 \%), 20-30$ years $(9,09 \%)$, and more than 30 years $(1,82 \%)$. This indicates that KUR program is provide convenience to access credit in BRI Unit Baron, Solo Branch Office.

Table 1 - Socio Economic Characteristics of the Samples of Debtors of People's Business Credit (KUR) Agribusiness Sector at BRI Unit Baron, Solo Branch Office

\begin{tabular}{|c|c|c|c|c|}
\hline No & Variable & & Frequency & Percentage \\
\hline \multirow[t]{2}{*}{1} & Sex & Male & 26 & 47,27 \\
\hline & & Female & 29 & 52,73 \\
\hline \multirow[t]{3}{*}{2} & Age & $<=30$ & 8 & 14,55 \\
\hline & & $31-60$ & 44 & 80 \\
\hline & & $>60$ & 3 & 5,45 \\
\hline \multirow[t]{4}{*}{3} & Education & Bachelor & 2 & 3,64 \\
\hline & & Senior High School & 30 & 54,55 \\
\hline & & Junior High School & 10 & 18,18 \\
\hline & & Primary School & 13 & 23,64 \\
\hline \multirow[t]{2}{*}{4} & Credit Experience & 1: Have a good credit experience & 47 & 85,45 \\
\hline & & $0:$ Otherwise & 8 & 14,55 \\
\hline \multirow[t]{4}{*}{5} & Net Income & $<=1$ Juta & 20 & 36,36 \\
\hline & & $1<X<2$ Juta & 21 & 38,18 \\
\hline & & $>2-3 \mathrm{jt}$ & 13 & 23,64 \\
\hline & & $>3$ jt & 1 & 1,82 \\
\hline \multirow[t]{6}{*}{6} & Credit Term & 12 Month & 3 & 5,45 \\
\hline & & 18 Month & 7 & 12,73 \\
\hline & & 24 Month & 28 & 50,91 \\
\hline & & 36 Month & 14 & 25,45 \\
\hline & & 48 Month & 1 & 1,82 \\
\hline & & 60 Month & 2 & 3,64 \\
\hline \multirow[t]{6}{*}{7} & Business Experience & $<5$ Thn & 21 & 38,18 \\
\hline & & $5-10$ Thn & 20 & 36,36 \\
\hline & & > 10 Thn - 20 Thn & 8 & 14,55 \\
\hline & & > 20 Thn - 30 Thn & 5 & 9,09 \\
\hline & & $>30$ Thn & 1 & 1,82 \\
\hline & Total & & 55 & 100 \\
\hline
\end{tabular}

Source: Field Survey, 2017.

Normality Test. First, to conduct a regression analysis it is advisable to test assumptions for the regression model before regressing the research variables (Ndungu, 2016). In this connection, normality test was conducted by Stata 12 Software. The data can be assumed to be normal if most of the data point tends to lie on a straight line. The normality test in this research uses Graph Test on the Stata. As shown in Figure 1, If the data point tends to lie on a straight line this means that the residuals in the research model are declared to be normally distributed. 


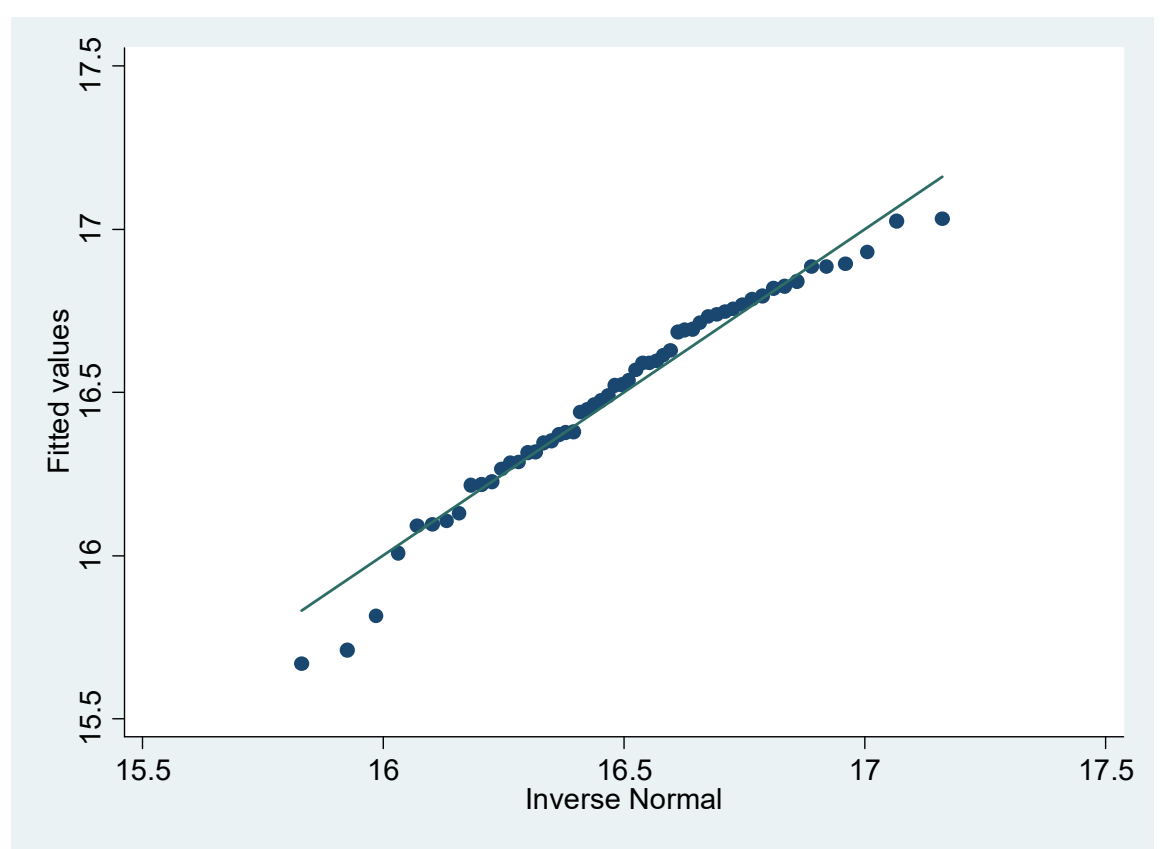

Figure 1 - Figure of Normality Test Result

Multicollinearity Test. The second test for regression classic assumption is multicollinearity. This was conducted by use of both tolerance and Variance Inflation Factor (VIF) . There was no multi-collinearity since the VIFs were less than 10 and none of the tolerance was less than 0.1 (Ndungu, 2016). Based on the results in Table 2 , it is known that all of the VIF value of the independent variable is less than 10, this means there was no multicollinearity between independent variables so that the independent variables can be used in the model.

Table 2 - Table of Multi-collinearity Test Result

\begin{tabular}{ccc}
\hline Variable & VIF & Tolerance \\
\hline Credit Experience & 1.11 & 0.902676 \\
Net Income & 1.10 & 0.9093220 .913587 \\
Credit period & 1.09 & 0.895959 \\
Business Experience & 1.12 & \\
\hline Mean VIF & 1.10 & \\
\hline
\end{tabular}

Source: Analysis (2017).

Heteroscedasticity Test. The third test for regression classic assumption is heteroscedasticity. Heteroskedasticity test in this research using Breusch-Pagan, if the value of "Prob> chi2" more than 0,05 , this means that in the regression model there is no heteroskedasticity. Based on Table 3 the value of Prob> chi2 is 0.1299 . This means that in the regression model there is no heteroscedasticity. So it can be said that the regression model used in this research is included in the criteria of a good regression model because it has a constant model error variance.

Table 3 - Table of Heteroscedasticity Test Result

\begin{tabular}{ll}
\hline Breusch-Pagan / Cook-Weisberg test for heteroskedasticity \\
\hline Ho & Constant variance \\
Variables & Fitted values of Intotalcredit \\
chi2(1) & 2.29 \\
Prob $>$ chi2 & 0.1299 \\
\hline
\end{tabular}

Source: Analysis (2017). 
$R$ Square $\left(R^{2}\right)$. R-squared is a statistical measure that represents the proportion of the variance for a dependent variable that's explained by an independent variable. Table 4 shows the statistical value of R-squares is 0,5974 . This means that all independent variables can explain the dependent variable by $59,74 \%$, while the remaining $100 \%-59.74 \%=40.26$ $\%$ was explained by other variables outside the regression model.

F-Test. The F-test can assess multiple coefficients simultaneously. This test aims to determine whether all independent variables together or overall affect the dependent variable. Table 4 shows the estimation results of value of F-test is 0,0000 . This means that all independent variables (credit experience, net income, credit period, business experience) together have a significant effect on the dependent variable (the number of realization of People's Business Credit in agribusiness sector) at a significant level of $1 \%$.

Table 4 - Table of Analysis Regression Result

\begin{tabular}{llll}
\hline Source & \multicolumn{1}{c}{ SS } & Df & MS \\
\hline Model & 5,41391028 & 4 & 1.35347757 \\
Residual & 3,64820472 & 50 & 0.072964094 \\
\hline Total & 9.38537164 & 54 & 0.167816945 \\
& & & \\
Number of Obs & 55 & & \\
$\mathrm{~F}(4,50)$ & 18.55 & & \\
Prob> F & 0.0000 & & \\
R-squared & 0.5974 & & \\
Adj R-squared & 0.5652 & & \\
MSE root & 0.27012 & & \\
\hline
\end{tabular}

Source: Regression Analysis Results (2017).

$t$-test. This test aims to determine whether independent variables by individually affect the dependent variable. Estimation results with regression function transformed into the form of Natural Log (Ln) can be seen from the value of $P>$ [t]. Based on Table 5, it can be seen that credit experience (X1), net income (X2), credit period (X3) and business experience variable (X4) proved to have a significant effect towards the amount of People's Business Credit in agribusiness sector at BRI Unit Baron, Solo Branch Office.

Table 5 - Table of Regression Analysis (t-test)

\begin{tabular}{lllll}
\hline Ln Total Credit & Coef. & Std.Err. & $\mathrm{t}$ & $\mathrm{P}>[\mathrm{t}]$ \\
\hline Ln Credit Experience & .2082352 & .1087367 & 1.92 & $0.0611^{* * *}$ \\
Ln Net Income & .6101381 & .077187 & 7.90 & $0.000^{* * *}$ \\
Ln Credit Period & .4111736 & .1136751 & 3.62 & $0.001^{* *}$ \\
Ln Business Experience & .0773648 & .0403604 & 1.92 & $0.061^{*}$ \\
Cons & 6.281585 & 1.23597 & 5.08 & 0,000 \\
\hline
\end{tabular}

Source: Regression Analysis Results (2017)

): Significant level at $10 \%$

$\left.{ }_{*}^{*}\right):$ Significant level at $5 \%$

(*): Significant level at $1 \%$

$\left.{ }^{n s}\right)$ : Not Significant

Credit Experience $\left(X_{1}\right)$. Credit experience variable $(X 1)$ are statistically have significant effect on the amount of People's Business Credit (KUR) at a 10\% significance level with a significance probability value of 0,061 . Credit experience coefficient shows the positive number 0,2082352 . This means that there is a positive influence between credit experience and the amount of People's Business Credit for agribusiness sector at BRI Unit Baron. It is because before the loan application is realized, the bank has previously sought information on whether the character of debtor is good or not in credit payment and there is no arrears in other banks by seeking Information in Indonesian Bank (BI) by using System application that called "BI Checking". The People's Business Credit or KUR program is a Government program. The debtors should not receiving other program credits from the Government except KUR program as proved by the BI Checking results when a credit application is 
submitted. Besides that, the debtors can receive a consumer credit and people's business credit (KUR) at BRI with a good collectability of 6 months.

The implication is if the respondent's credit experience previously was good, the BRI's officer would giving more amount of credit to them. Due to the fact, the good repayment of debtors, could be consideration for BRI's officer in taking credit approval decision. By knowing their credit history, the BRI's officer could assess how well they can manage their credit on a limited scale before taking on larger amounts of credit.

This research agrees with the findings of (Mensah \& Agbekpornu, 2015) that other income, membership of business organization, firm size, borrower/credit experience, collateral security, and credit management skills were found to be statistically significant determinants of credit accessibility. Also the findings of (Lemessa \& Gemechu, 2016) that experience in credit use from the formal sources is a significant variable that affects access to formal credit. They conclude that farmers experience in credit use from the formal financial institutions plays an important role in accessing credit from these institutions. In line with that (Nwaru et al., 2011) stated that the coefficient for experience in lending was significant at $10 \%$ and has a positive relationship with credit supply.

The results of this research are also in accordance with the research hypothesis. The BRI's officer feels more sure to give more amount of credits if the respondents have good character in terms of fulfilling their obligations to the Bank in paying installments. The better their credit experience, the higher the amount of People's Business Credit (KUR) for agribusiness sector at BRI Unit Baron, Solo Branch Office.

Net Income $\left(X_{2}\right)$. Net income are statistically have a significant effect on the amount of People's Business Credit (KUR) at $1 \%$ significance level with a significance probability value of 0,000 . Net income coefficients indicates the positive number of 0,6101381 . This means that there is a positive influence between net income and the amount of People's Business Credit for agribusiness sector at BRI Unit Baron. So it can be concluded that if net income is increases, the amount of People's Business Credit for agribusiness sector will further increase. Due to the fact, the higher of net income could be consideration for BRI's officer to measured their ability in making payments as a liability to the Bank. Income level is one of the criteria that shows the ability or capacity of the respondent's business feasibility. By knowing the level of income of debtors will affect the debtor's return on installment obligations that must be paid later.

The results of this study are also in line with (Cheng, 2007) the demand for micro-loans is positively related to the house- hold incomes, the opportunities for off-farm investment and the educational level of female borrowers. In line with the results of the study of (Nwaru et al., 2011) The co-efficient of farm income was statistically significant at $1 \%$ and, in conformity with a priori expectations, it was positively signed. Ceteris paribus, increase in farm income would lead to increased saving which could be re-invested leading to increased business activities and a concomitant increase in credit demand. Moreover, lenders would prefer to grant credit facilities to farmers whose income is high because they have higher chances of repaying the loan.

Therefore, it can be concluded that the analysis results of this study indicate conformity with previous studies and show support for the research hypothesis. The implication is that, the higher net income, the higher the amount of People's Business Credit (KUR) for agribusiness sector at BRI Unit Baron, Solo Branch Office.

\section{Credit Term $\left(X_{3}\right.$}

Credit term are statistically have a significant effect on the amount of People's Business Credit (KUR) at $1 \%$ significance level with a significance probability value of 0,001 . Credit term coefficients indicates the positive number of 0,4111736 . This means that there is a positive influence between credit term and the amount of People's Business Credit for agribusiness sector at BRI Unit Baron .

According to Ajagbe et al., (2012) The period of obtaining credit is positively correlated with personal savings which shows that the longer the payback period the higher the amount of credit secured from the scheme and the higher the income generated. 
The results of this study indicate suitability with research advance and support the hypothesis statement that credit term is significant effect on the amount of People's Business Credit. The implication is that, the longer credit term, the higher the amount of People's Business Credit (KUR) for agribusiness sector at BRI Unit Baron, Solo Branch Office.

Business Experience $\left(X_{4}\right)$. Business Experience are statistically have a significant effect on the realization of People's Business Credit (KUR) at $10 \%$ significance level with a significance probability value of 0,061 . Business Experience coefficients indicates the positive number of 0,0773648 . This means that there is a positive influence between business experience and the amount of People's Business Credit for agribusiness sector at BRI Unit Baron. So it can be concluded that if business experience is increases, the amount of People's Business Credit for agribusiness sector at BRI Unit Baron will further increase. This implies that the bank's officer more sure giving more amount of credit to the business that much longer stand up. It means the business could be considered more stabble and grow larger.

However, the results of these studies contradictive with previous studies by (Gbadebo et al., 2013) that business experience variables were positively marked but had no significant effect on credit. But this research agrees with the study of Munene \& Guyo, (2013) that the business experience have a significant effect to the failure of micro-credit refund. So it can be concluded that the results of the research support the hypothesis statement that the experience business has a significant effect on the number of realization of People's Business Credit for agribusiness sector in BRI Unit Baron, Solo Branch Office. The implication is that, the higher of business experience, the higher the number of realization of People's Business Credit (KUR) for agribusiness sector at BRI Unit Baron, Solo Branch Office.

\section{CONCLUSION AND SUGGESTIONS}

The variable of credit experience has positive effect on the amount of People's Business Credit. Due to the fact, the good repayment of debtors, could be consideration for BRI's officer in taking credit approval decision. By knowing their credit history, the BRI's officer could assess how well they can manage their credit on a limited scale before taking on larger amounts of credit. Net Income variable has positive effect on the amount of People's Business Credit. One of the explanation is by knowing the level of debtors income will affect the debtor's return on installment obligations that must be paid later. Income level is one of the criteria of BRI's officer that shows the ability or capacity of the respondent's business feasibility. Based on the credit term, it has a positive effect on the amount of People's Business Credit. The longer credit term, the higher the amount of People's Business Credit (KUR) for agribusiness sector at BRI Unit Baron, Solo Branch Office. This is partly explained by the fact that the patterns and regularity of repayment over longer periods of time will give more favorably in the assessment of credit by BRI's officer. The longer credit term could be one of the consideration for BRI's officer in taking credit approval decision. The variable of business experience has positive effect on the amount of People's Business Credit. This implies that the bank's officer more sure giving more amount of credit to the business that much longer stand up. It means the business could be considered more stabble and grow larger.

Based on the results of the research and the problems of MSEMs in accessing credit, it can be suggested for development of MSMEs of agribusiness sector that they should having a repayment good record in a length of credit, increasing their business capacity so it can increase their income and measured their capability and willingness to repayment the credit, and increasing their age of the business by skill, knowledge and experience, so they can easier access to credit in formal institutions and also is simultaneously, the maker of policy can give an easier policy to access the credit in formal institution or they can give another credit program that can help the MSEs to increase their business scale. 


\section{REFERENCES}

1. Ajagbe, F. A., Oyelere, B. A., \& Ajetomobi, J. O. (2012). Determinants of Small-Scale Enterprise Credit Demand: Evidence from Oyo State, Nigeria. American Journal of Social and Management Sciences, 3(1), 45-48. https://doi.org/10.5251/ajsms.2012.3.1.45.48

2. Alabi, O. O., Lawal, A. F., \& Chiogor, H. O. (2016). Access to Formal Credit Facilities Among Smallscale Crop Farmer's in Gwagwalada Area Council, Abuja, Nigeria. Russian Journal Oof Agricultural and Socio-Economic Sciences (RJOAS), 1(January). https://doi.org/DOI: 10.18551/rjoas.2016-01.07

3. Balogun, O. ., \& Yusuf, S. . (2011). Determinants Of Demand For Microcredit Among The Rural Households in South-Western States, Nigeria. Journal of Agriculture and Social Science, 7 No.2, 41-48. https://doi.org/10.9790/2380-071130109

4. Cheng, E. (2007). The Demand For Microcredit As A Determinant For Microfinance Outreach - Evidence from China. Savings and Development Journal, 31(3), 307-334.

5. Darwin. (2018). UMKM Dalam Perspektif Pembiayaan Inklusif Di Indonesia. Jurnal Ekonomi Dan Pembangunan, 26 No.1, 59-76.

6. Daryanto, A. (2009). Seminar Nasional (pp. 1-33). Bogor: Pusat Analisis Sosial Ekonomi dan Kebijakan Pertanian.

7. Friyanto, S., \& Saptana. (2017). Kinerja Agribisnis Komoditas Pertanian: Kemampuan Penciptaan Output, Nilai Tambah dan Keterkaitan antar Sektor (Analisis Komaparasi IO tahun 2005 dan 2010). Manajemen Dan Agribisnis, 14(3), 250-263. https://doi.org/Permalink/DOI: http://dx.doi.org/10.17358/jma.14.3.250

8. Gbadebo, A. W., Ademayowa, A. A., Mobolaji, A. W., \& Ayanyemi, A. A. (2013). Determinants of Farmers' Demand for Micro Finance: The Case of a Rural Community in Nigeria. Journal of Economics and Sustainable Development, 4(5), 24-31. Retrieved from www.iiste.org

9. Hutadjulu, L. Y., \& Blesia, J. U. (2016). Factors That Affect The Perception of Small and Medium-Sized Businesses (SMEs)' Community on The Importance of Financial Statements, The Amount of Credit Received and Implementation Prospects. International Conference on Social Science and Biodiversity of Papua and Papua New Guinea (ICSBP 2015), 1(1), 125-135. https://doi.org/10.18502/kss.v1i1.444

10. Khandker, S. R. (2005). Microfinance and poverty: Evidence using panel data from Bangladesh. The World Bank Economic Review, 19(2), 263-286. https://doi.org/10.1093/wber//hi008

11. Kisaka, S. E., \& Mwewa, N. M. (2014). Effects of Micro-Credit , Micro-savings and Training on the Growth of Small and Medium Enterprises in Machakos County in Kenya. Research Journal of Finance And Accounting, 5(7), 43-50. Retrieved from www.iiste.org

12. Lemessa, A., \& Gemechu, A. (2016). Analysis of Factors Affecting Smallholder Farmers ' Access to Formal Credit in Jibat District, West Shoa Zone , Ethiopia. International Journal of African and Asian Studies, 25(2016), 43-53.

13. Luvhengo, U., \& Lekunze, J. N. (2017). Identifying Factors That Influence Small-Scale Farmers' Access to Credit From Commercial Banks in Greater Taung Municipality, North West Provine, South Africa. Journal of Agribusiness and Rural Development, 3(45). https://doi.org/http://dx.doi.org/10.17306/J.JARD.2017.00331 Journal

14. Maulidah, S. (2012). Sistem Agribisnis. Fakultas Pertanian Universitas Brawijaya Malang. 15. Mensah, S. O., \& Agbekpornu, H. (2015). Determinants of Access to Credit by Agribusiness Operators in the Kumasi Metropolis, Ghana. American Journal of Experimental Agriculture, 6(5), 333-346. https://doi.org/10.9734/AJEA/2015/12477

16. Munene, H. N., \& Guyo, S. H. (2013). Factors influencing loan repayment default in micro-finance institutions: The experience of Imenti North District, Kenya. International Journal of Applied Science and Technology, 3(3), 80-84.

17. Nader, Y. F. (2008). Elsevier Journal. Elsevier Journal, 37(2), 644-656.

18. Ndungu, C. W. (2016). Factors Affecting Credit Access Among Small and Medium Enterprises in Murang' A County. Disertasi.The Degree Of Master Of Business Administration In Finance At The University Of Nairobi. 
19. Nurif, M., \& Mukhtar, S. (2010). Pembangunan Ekonomi Berbasis Agribisnis Sebagai Wujud Pembangunan Ekonomi Yang Berkelanjutan. Jurnal Sosial Humaniorah, 3(2), 124-138.

20. Nwaru, J. ., Essien, U. A., \& Onuoha, R. E. (2011). Determinants of Informal Credit Demand and Supply among Food Crop Farmers in Akwa Ibom State, Nigeria. Journal of Rural and Community Development, 6(1), 129-139.

21. Ofonyelu, C. C., \& Alimi, R. S. (2013). Perceived Loan Risk and Ex Post Default Outcome: Are the Banks ' Loan Screening Criteria Efficient? Asian Economic And Financial Review, 3(8), 991-1002.

22. Ratnaningtyas, W., Topowijono, \& Z.A, Z. (2016). Evaluasi Kelayakan Pemberian Kredit Usaha Rakyat Untuk Mencegah Terjadinya Kredit Bermasalah (Studi Kasus Pada PT. Bank Rakyat Indonesia (Persero), Tbk. Cabang Kawi Malang). Jurnal Administrasi Bisnis (JAB), 39 No.1(2), 34-42.

23. Rivai, V., \& Veithzal, A. P. (2007). Credit Management Handbook. Jakarta: PT Rajagrafindo Persada.

24. Taj, S., Akmal, N., Shah, N. A., Ahmad, S., \& Saddozai, K. N. (2008). Gender Involvement in Small Enterprises Through Micro-Credit in Rainfed Pothwar. Sarhad Journal Agriculture, 24(4).

25. Tether, B., A., Mina, D. C., \& Gagliardi, D. (2005). A literature review on skills and innovation: How does successful innovation impact on the demand for skills and how do skills drive innovation? Manchester.

26. Wabei, S. (2012). Determinants Of Household Credit Demand In Zambia. Disertasi Degree of Master of Arts in Economics. The University of Zambia. Lusaka.

27. Zhao, H., Wu, W., \& Chen, X. (2006). What Factors Affect Small and Medium-sized Enterprise 's Ability to Borrow from Bank: Evidence from Chengdu City , Capital of There Are Many Factors That Affect SMEs' Ability to Borrow From Bank. Based on Facts. Berlin. 